\title{
MANIS TETRADACTYLA.
}

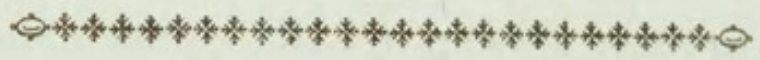

\section{CHARACTER GENERICUS.}

Dentes nulli.

Lingua teres, extenfilis.

Os anguftatum in roftrum.

Corpus fquamis tectum.

$$
\text { Lin. Syft. Nat. p. } 52 \text {. }
$$

CHARACTER SPECIFICUS, ङC.

MANIS pedibus tetradactylis.

$$
\text { Lin. Syft. Nat. p. } 53 \text {. }
$$

LACERTUS fquamofus peregrinus.

$$
\text { Clus. Exot. } 374 \text {. }
$$

Tam prope accedit hæc Manis fpecies ad fimilitudinem Manis Pentadactylæ, in priore numero hujus operis depictx, ut a quibufdam phyficis varietas potius quam fpecies diftincta cenfeatur. Linnæus etiam ipfe, cum characterem illi fpecificum ftatuerit, addit, "præcedenti nimis affinis." Caudæ tamen longitudo, quæ in omnibus fpeciminibus a meipfo obfervatis, illam Manis Pentadactylæ longe fuperat, fquamæque magis oblongæ, acuminatæ etiam et ftriatæ, feu fulcatæ, nec non corporis forma gracilior, cum aliis differentiis, quæ accurate perpendenti phyfico patebunt, clare demonftrant 
monftrant hanc fpeciem alteram omnino et diverfam effe. Quod ad habitus vitæque mores attinet, ea omnia in hiftoria alterius fpeciei antea defcriptæ numerantur. Nihil igitur reftat, quin ut illam ipfam defcriptionem adeat lector. 


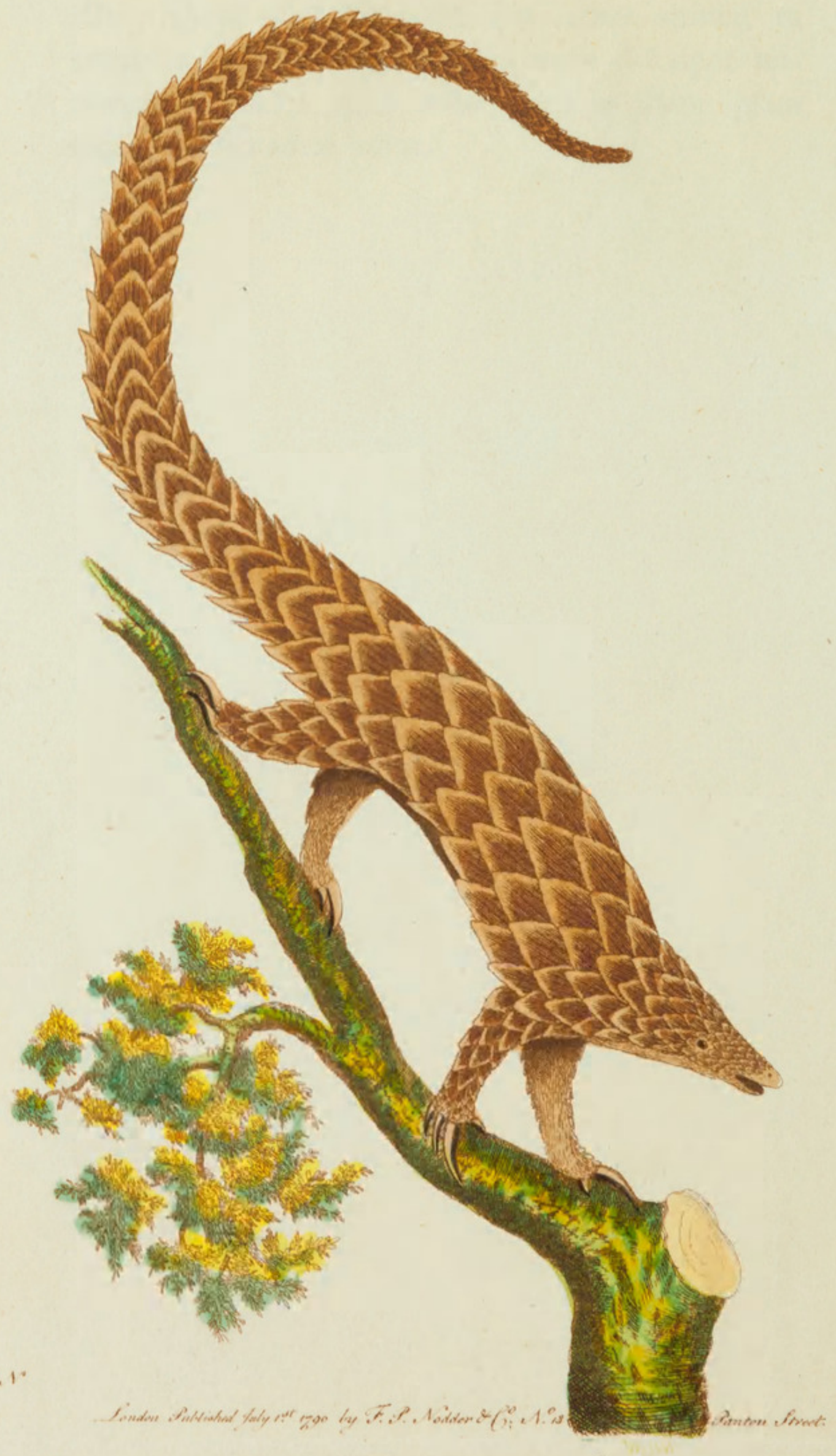




\section{T H E \\ FOUR-TOED MANIS.}

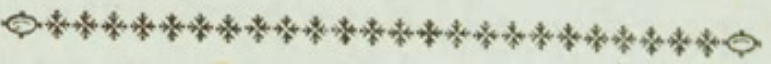

GENERIC CHARACTER.

No Teeth.

Tongue cylindric and extenfile. Mouth narrowed into a fnout. Body covered with fcales.

SPECIFIC CHARACTER, $\Theta^{2}$.

MANIS with tetradactylous (or four-toed) feet. Lin.

\section{LONG-TAILED MANIS.}

Pennant. Hift. Quadr. p. 504.

This fpecies of Manis makes fo very near an approach to the Manis Pentadactyla, figured in a former number of this work, that it has been regarded by fome Naturalifts as a variety rather than a diftinct fpecies; and Linnæus in his Syftema Naturæ, after giving its fpecific character, obferves that it is almoft too nearly allied to the other to be regarded as diftinct. The length of the tail however, which in all the fpecimens I have ever,obferved, very greatly exceeds the proportion of the fame part in the former fpecies, as well as the more oblong and even acurninate form of the furrowed or ftriated fcales, together with a greater degree of flendernefs in 
the body, and fome other particulars which an attentive furvey difcovers, feem clearly to prove a real fpecific difference. In point of general habits and mode of life nothing need be added to what has been already faid of the other fpecies, or M. Pentadactyla, to which the reader is therefore referred for its hiftory. 


\section{$2 \mathrm{BHL}$ Biodiversity Heritage Library}

Shaw, George. 1790. "The Four-Toed Manis, Manis tetradactyla [PI. 36]." The Naturalist's Miscellany 1(XII), https://doi.org/10.5962/p.310688.

View This Item Online: https://www.biodiversitylibrary.org/item/281460

DOI: https://doi.org/10.5962/p.310688

Permalink: https://www.biodiversitylibrary.org/partpdf/310688

\section{Holding Institution}

Museums Victoria

\section{Sponsored by}

Atlas of Living Australia

\section{Copyright \& Reuse}

Copyright Status: Public domain. The BHL considers that this work is no longer under copyright protection.

This document was created from content at the Biodiversity Heritage Library, the world's largest open access digital library for biodiversity literature and archives. Visit BHL at https://www.biodiversitylibrary.org. 